\title{
Cold fronts and reservoir limnology: an integrated approach towards the ecological dynamics of freshwater ecosystems
}

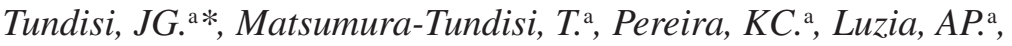 \\ Passerini, MD. ${ }^{\mathrm{a}}$, Chiba, WAC. ${ }^{\mathrm{a}}$, Morais, MA. ${ }^{\mathrm{a}}$ and Sebastien, $N$. $^{\mathrm{b}}$ \\ anstituto Internacional de Ecologia - IIE, Rua Bento Carlos, 750, Centro, CEP 13560-660, São Carlos, SP, Brazil

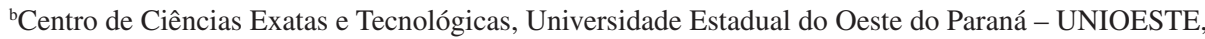 \\ Rua da Faculdade, 645, Jardim La salle, CP 520, CEP 85903-000, Toledo, PR, Brazil \\ *e-mail: tundisi@iie.com.br
}

Received January 08, 2010 - Accepted June 05, 2010 - Distributed October 31, 2010

(With 7 figures)

\begin{abstract}
In this paper the authors discuss the effects of cold fronts on the dynamics of freshwater ecosystems of southeast South America. Cold fronts originating from the Antarctic show a monthly frequency that promotes turbulence and vertical mixing in reservoirs with a consequence to homogenize nutrient distribution, dissolved oxygen and temperature. Weak thermoclines and the athelomixis process immediately before, during and after the passage of cold fronts interfere with phytoplankton succession in reservoirs. Cyanobacteria blooms in eutrophic reservoirs are frequently connected with periods of stratification and stability of the water column. Cold fronts in the Amazon and Pantanal lakes may produce fish killings during the process of "friagem" associated mixing events. Further studies will try to implement a model to predict the impact of cold fronts and prepare management procedures in order to cope with cyanobacteria blooms during warm and stable water column periods. Changes in water quality of reservoirs are expected during circulation periods caused by cold fronts.
\end{abstract}

Keywords: cold fronts, ecological dynamics, reservoirs, stability, turbulence, cyanobacteria blooms, water quality.

\section{Frentes frias e limnologia de reservatórios: uma abordagem integrada para a dinâmica ecológica dos ecossistemas de águas interiores}

\section{Resumo}

Neste trabalho, os autores discutem o impacto das frentes frias na dinâmica dos ecossistemas de água doce da região sudeste da América do Sul e com repercussões no Centro Oeste e Amazônia. Frentes frias com origem no continente Antártico mostram uma frequência mensal que tem como consequência o aumento da turbulência e a mistura vertical em represas, homogeneizando a distribuição de nutrientes, de oxigênio dissolvido e a temperatura da água. Termoclinas fracamente estabilizadas e o processo de atelomixia imediatamente antes, durante e após a passagem das frentes frias intervêm na sucessão fitoplanctônica em represas. Frentes frias na Amazônia e Pantanal podem ser a causa da mortalidade em massa de peixes devido à remoção das camadas anóxicas do fundo dos lagos de várzea (friagem). Florescimentos de cianobactérias em reservatórios eutróficos são frequentemente relacionados com períodos de estratificação e estabilidade vertical da coluna de água. Futuros estudos deverão implementar um modelo preditivo que poderá ser fundamental no gerenciamento de reservatórios de abastecimento de água. Estes modelos terão a capacidade de prever frequência de florescimentos de cianobactérias e gerenciar melhor a qualidade da água desses reservatórios.

Palavras-chave: frentes frias, dinâmica ecológica, reservatórios, estabilidade, turbulência, florações de cianobactérias, qualidade da água. 


\section{Introduction}

The continuous motion that is a characteristic feature of the pelagic environment is a fundamental forcing function in the spatial and temporal organization of the phytoplanktonic community. Turbulence of various scales sets up the pattern of succession and spatial distribution, and this relationship is now well known (Reynolds, 1997). The vertical structure of turbulent layers depends upon the wind velocity and direction and, the depth of the freshwater ecosystem; the kinetic energy of mixing is opposed by the degree of density stratification. Therefore a continuous process of turbulent mixing and density stratification occurs in lakes and reservoirs promoting a pulse system of fluctuation, that, accordingly to many authors (Harris, 1980, 1986; Padisak, 1993; Padisak et al., 2993) is what influences the species richness, diversity and equitability of phytoplankton in shallow lakes. Evidences of the impact of climatological factors such a precipitation and wind in the southern hemisphere and particularly in Brazil can be found in the literature as early as 1979 (Lima et al., 1979; Tundisi, 1983).

The importance of climatological data for studies in limnology of lakes and reservoirs was stressed by Tundisi et al. (2007) based or earlier work at UHE Carlos Botelho (Lobo/Broa) reservoir that showed strong interactions between wind, precipitation and the seasonal succession of phytoplankton (Tundisi and Matsumura Tundisi, 1995). More recent evidences of the impact of climate on the functioning of reservoirs at southeastern Brazilian given by Branco et al. (2009) emphasized the interactions of climate variables such as wind, air temperature and precipitation with the thermal, chemical and biological structure of the water column at Lages Reservoir (Brazil).

Earlier work on the ecological importance of cold fronts in reservoirs of southern Brazil showed also strong interactions between the passages of the southern air masses and the circulation patterns of reservoirs (Arcifa et al., 1990; Tundisi et al., 2004, 2006).

Barbosa and Padisak (2002) described how atelomixis in lakes and reservoirs is a fundamental process in the daily reorganization of the thermal structure of the water column interacting thus with the phytoplankton vertical distribution and succession in shallow lakes.

In this paper the authors describe with further details and information the impact of cold fronts in freshwater ecosystems of Brazil. This is an attempt to develop and promote an integrated approach and overview of the cold fronts impact in the functioning of reservoirs with the aim to introduce a conceptual framework and the development of a predictive limnological/ecological attitude towards the management of these shallow artificial aquatic ecosystems at southeast Brazil.

\section{Material and Methods}

\subsection{Data collection: literature sources and experimental data}

Data from the literature showing vertical distribution of physical variables under the impact of the cold fronts were collected and assembled from many sources in the recent literature (Tundisi et al., 2004, 2006).

Several unpublished results from the laboratories of the International Institute of Ecology of São Carlos were also analyzed (Passerini, 2010). These results are part of the project on real time monitoring of physical and chemical variables developed for DERSA (State of São Paulo Government), in connection with the monitoring of Billings and Guarapiranga reservoirs. Real time monitoring was performed with a SMARTER plataform and satellite transmission of data (Patent deposited IIE).

Recent data from papers on the ecological dynamics of a shallow reservoir (Tundisi et al., 2008a) and the climatology of cold fronts on the Metropolitan region of São Paulo are also analyzed (Morais et al., 2010).

\subsection{Analysis of cold fronts frequencies and variability in South America}

The results and data presented by Cavalcanti and Kousky (2009) are summarized as a basic information for the cold front - reservoir limnology case study. The data for South Eastern Brazil presented by these authors is discussed.

\subsection{The dynamics of the cold fronts in the South American continent and the Southeast Brazil}

Accordingly with Cavalcanti and Kousky (2009), there is seasonality in the occurrence of the cold fronts passage in the South American continent. The cold fronts are more frequent from May to September and less frequent during the summer in the southern hemisphere between the latitudes $25^{\circ}$ and $30^{\circ}$, cold fronts occur during all year round but in greater number from May to October.

Figure 1 shows the average number of cold fronts from 1980 to 2002. For comparative purposes the monthly regime of cold fronts in the metropolitan region of São Paulo is shown in Figure 2.

For the southeast region of Brazil, Cavalcanti and Kousky (2009) showed a yearly frequency of 50 to 60 cold fronts. Also these authors demonstrated an excellent relationship between the cold fronts and the atmospheric variables such as air temperature, (lower air temperatures) increase of atmospheric pressure at sea level, and increase in wind velocity. Also an effect on the intensity and distribution of precipitation occurs. An increase in the precipitation is typical during the passage of cold fronts. Figure 3 shows a typical progression of cold fronts in the southeast Brazil. The dynamics of the process last for hours to lays accordingly with the existing data.

\section{Results}

Figure 4 shows the changes during the cold fronts in Barra Bonita reservoir related to the vertical structure of the water column, temperature and stability (Tundisi et al., 2006) and thermal resistence to circulation.

Figure 5 shows the same reservoir under the effects of the cold front. 


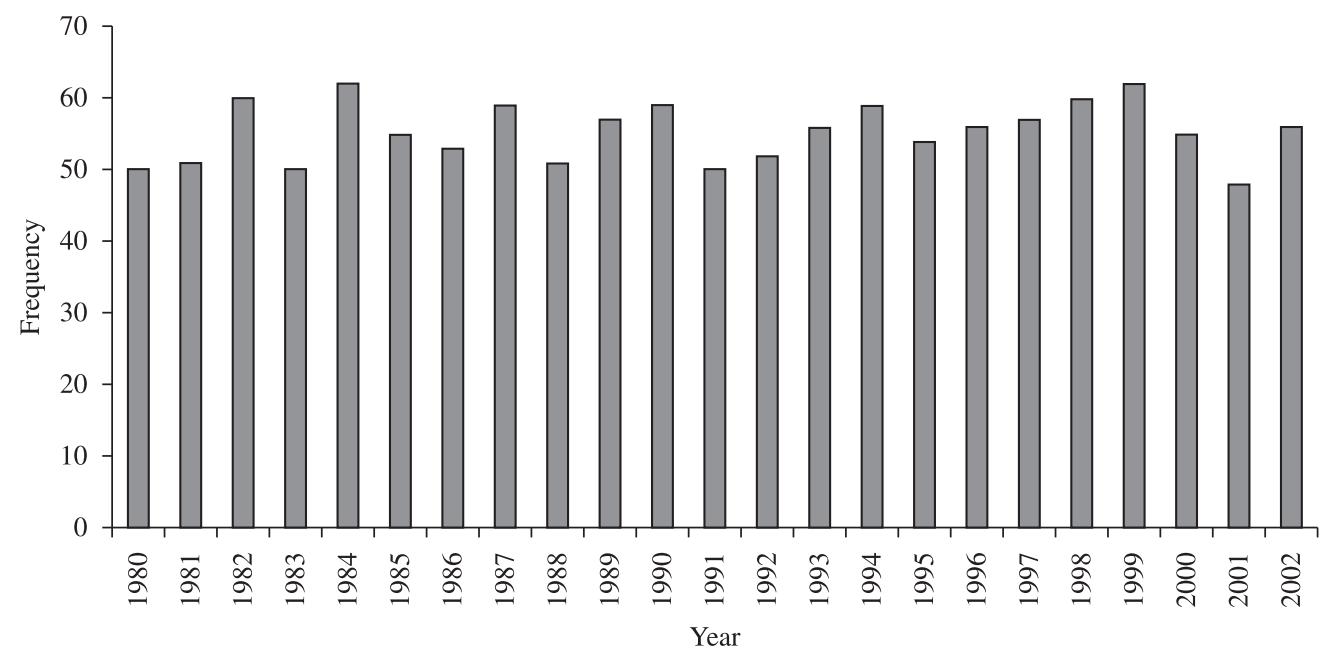

Figure 1. Annual frequency of frontal system for the south eastern region of South America. Source: Andrade (2005).

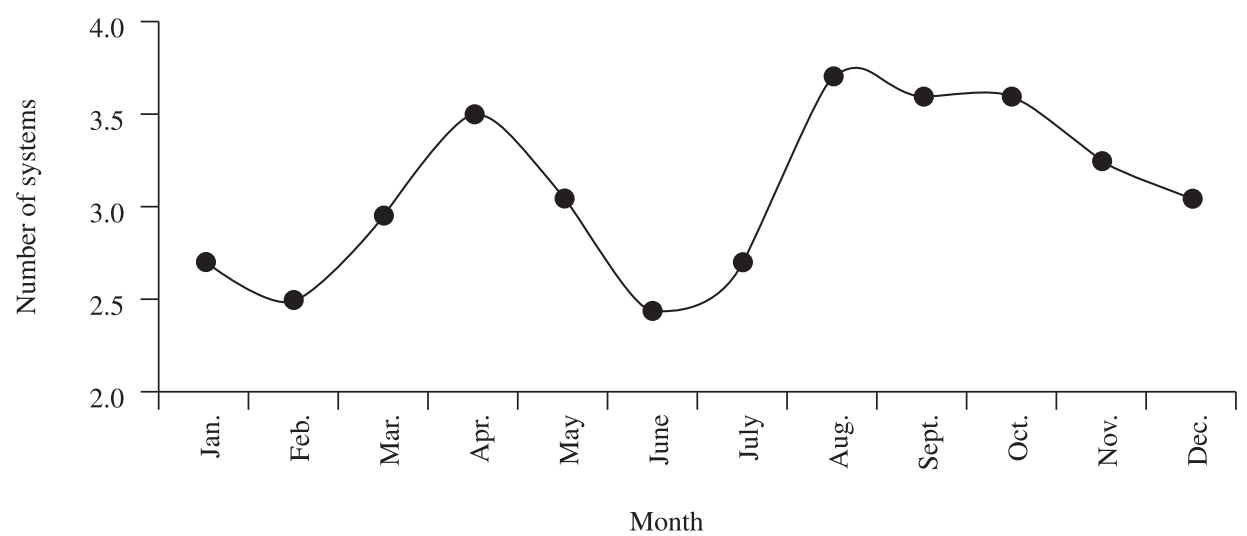

Figure 2. Monthly number of cold fronts on the Metropolitan Region of São Paulo, 1987-2007. Source: Morais et al.. (2010).

Figure 6 a shows the vertical structure of the water column at Billings reservoir during December 2007. The presence of the cold fronts is indicated. Periods of stratification and stability, work of the wind and thermal resistance to circulation during the same period are shown. The system repeats in March 2008 of the same station in Billings reservoir; low stability and low thermal resistance to circulation related to the cold fronts effects (Figure 7a and $7 \mathrm{~b})$.

Caraballo et al. (2010, in press) observed and reported the impact of a cold front ("friagem") in May 2006 in lake Catalão located at the confluence of the Negro river and Solimões river in front of the city of Manaus ( $3^{\circ} 10^{\prime} 04^{\prime \prime} \mathrm{S}$ and $\left.59^{\circ} 54^{\prime} 45^{\prime \prime} \mathrm{W}\right)$. On the second day of the "friagem" accordingly to these authors, the 12 meter water column of the lake was completely mixed with a temperature of $27,8^{\circ} \mathrm{C}$. Low levels of oxygen in the water near the surface of the lake were found as a consequence of destratification and mixing coupled with the "friagem" event and impact. The cold front impact caused a significant temperature difference during the nictimeral cycle. During this event hydrogen sulfide gas and dead fish were not found. However in other episodes of cold fronts this is a common feature in Amazonian and Pantanal floodplain lakes (Fearnside, 1995;). Surface cooling and strong density currents promoting complete mixing even in lakes deeper than 10 meters were reported by Tundisi et al. (1984); Melack and Fisher (1990).

In conclusion, all the existing experimental evidence and literature sources show a strong effect of cold fronts in reservoirs of southeast Brazil and in Amazon and Pantanal lakes. These sources, clearly demonstrated that cold fronts are a significant forcing function coupled with climatic variation that affects these freshwater ecosystems at a wide range of latitudes in South America. 

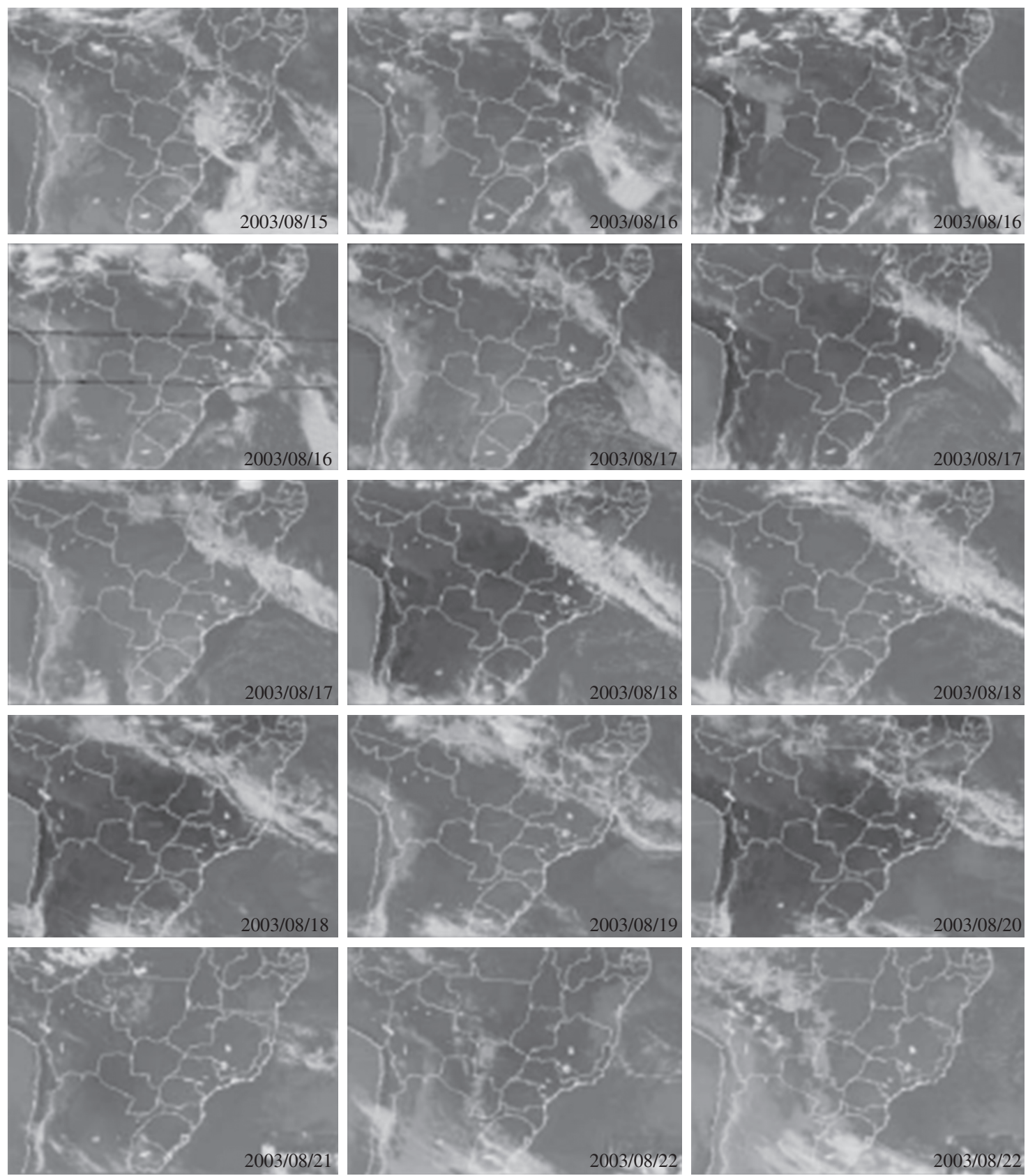

Figure 3. Sequences of satellite images showing the propagation and dissipation of cold fronts from 2003/08/15 to 13.15 hours to 2003/08/22 to 23.10 hours. Source: Tundisi et al. (2004).

\section{Discussion}

There is now strong evidence that cold fronts are a fundamental forcing function in the mixing of reservoirs and natural lakes mainly in the southeast Brazil and at Amazonian and Pantanal lakes.

The vertical and horizontal mixing that takes place after the passage of cold fronts has impacts and consequences on the phytoplankton succession and in the mixing patterns of the freshwater ecosystems.

When cold fronts are operating in full scale the cooling of the surface waters and the vertical mixing changes the thermal structure of lakes and reservoirs producing homogeneous profiles of water temperature, dissolved oxygen, electrical conductivity of the water and nutrients, such as phosphorus and nitrogen (Tundisi et al., 2004, 2006; 

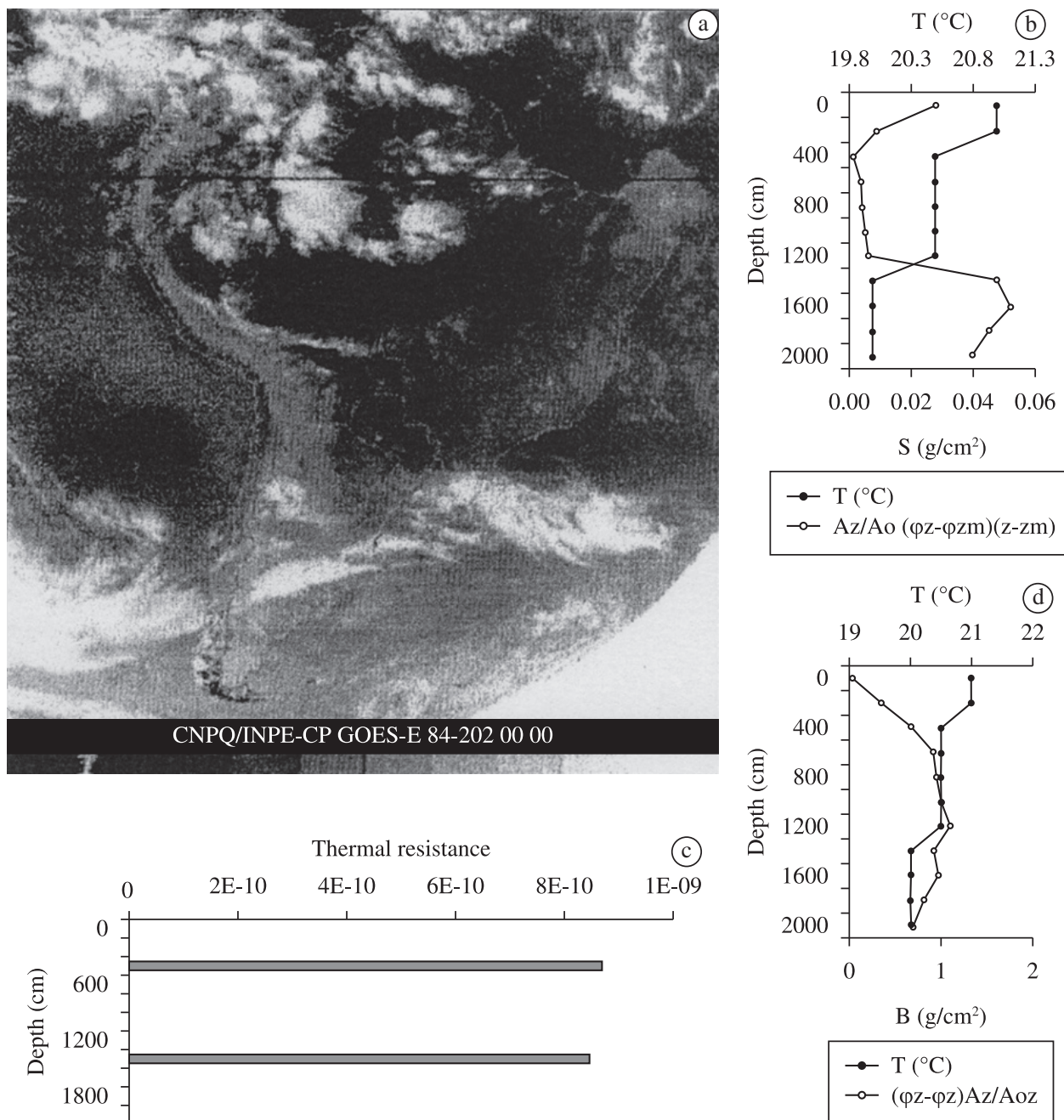

Figure 4. a) Satellite images showing area clear of cold front in southeast Brazil during July (20/07/1984); b) vertical structure of the water column temperature and stability; and c) thermal structure and wind work in the water column of the reservoir Barra Bonita reservoir. Source: Tundisi et al. (2006).

Branco et al., 2009; Morais et al., 2010; Caraballo et al., 2010).

Cold fronts originating in southern South America present a seasonal variation as demonstrated by Cavalcanti and Kousky (2009), and discussed by Morais et al. (2010).

In an environment characterized by reduced wind impact there is a lack of mixing and predominance of cyanobacteria blooms of the surface and subsurface of the water column. Tundisi (1983) demonstrated that for reservoirs of the Tiete river in São Paulo State growth and prevalence of cyanobacteria blooms are depending on the stability of the water column, the average depth of the stratified column and the radio N:P. During periods of stability of the water column the mixed layer is depleted of nutrients very rapidly therefore phytoplankton should depends on the nutrient regeneration and the ability of cyanobacterias to fix nitrogen. Increase of ammonia in the stratified layer due to zooplankton excretion is another possible source of nitrogen regeneration (Tundisi, 1983).

Intense turbulence immediately before and during the cold fronts establishes the mixing in the vertical and horizontal scales promoting the growth of chlorophyceae and diatoms during these short periods of 2 or 3 days.

Harris et al. (1986) emphasized the effect of physical factors in the control of phytoplankton dynamics and discussed the time scales of physical fluctuations coupled with the response of the phytoplanktonic community. Several authors demonstrated the response of the phytoplankton related to the extent and degree of vertical turbulence (Ganf, 1974; Reynolds, 1997). The ratio of the euphotic zone ( $\mathrm{Zeu}$ ) to the depth of the mixed layer ( $\mathrm{Zmix}$ ) is a fundamental physical component, of critical depth models as shown by Harris (1980).

Turbulence promoted by cold fronts changes very rapidly this ratio Zeu/Zmix therefore physiological adaptation 

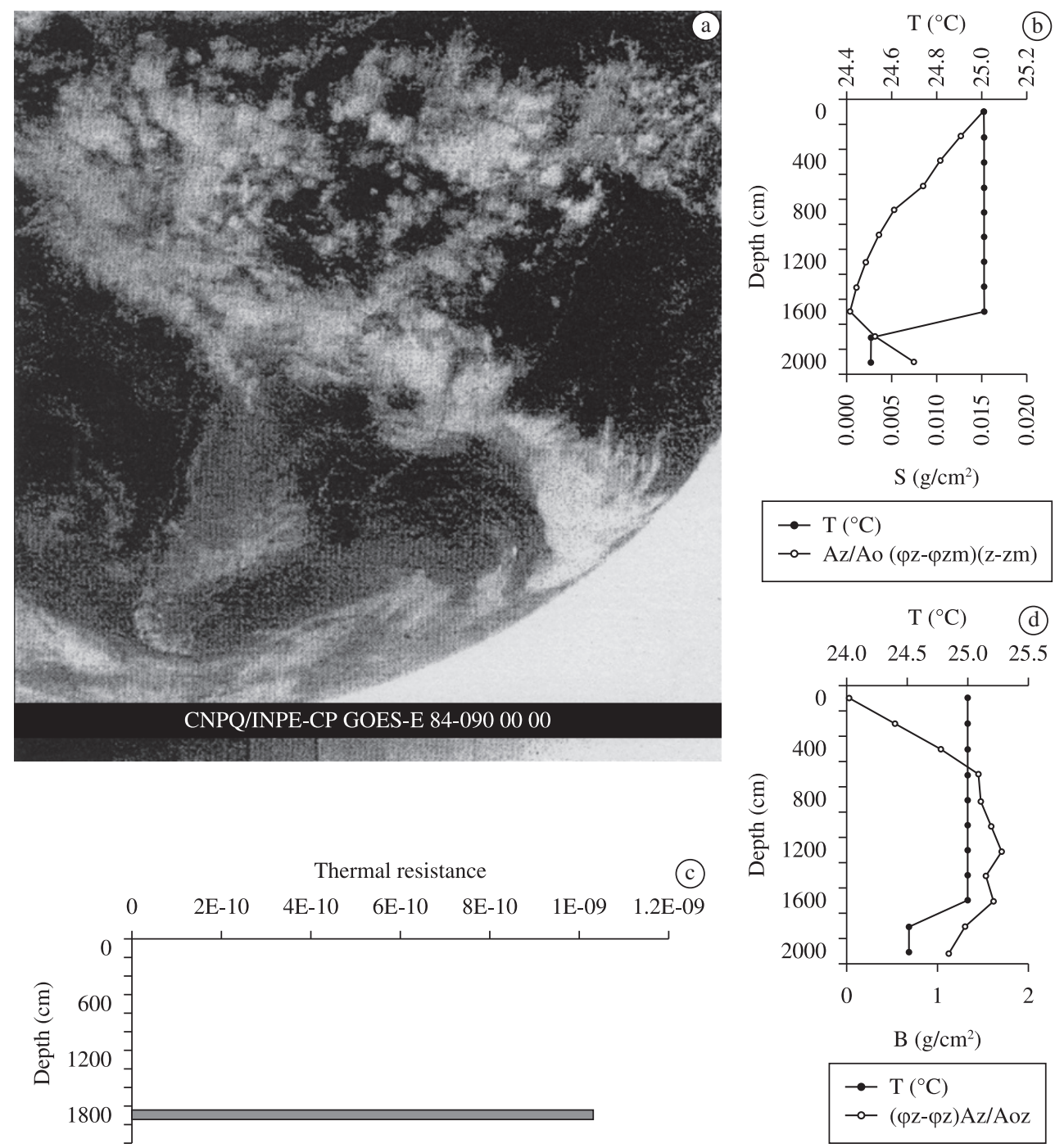

Figure 5. a) Satellite image showing cold front in the southeast Brazil during March (30/3/1984); b) vertical Structure of the water column. Temperature and stability; c) thermal resistance to circulation; and d) thermal Structure and, wind, work in the water column of the reservoir Barra Bonita reservoir. Source: Tundisi et al. (2006).

of the phytoplankton to these short time changes can be expected. But besides these physiological adaptations, the physical forcing functions promoted by turbulence before and during the cold fronts changes the succession patterns of phytoplankton; changes in the growth rates of phytoplankton due to varying nutrient concentration may be expected also (William and Goldman, 1975).

Tundisi et al. (2008a) showed how the patterns of phytoplankton succession changes at Barra Bonita reservoir during alternating periods of cold front impacts and stability of the water column. Wind velocities, frequency of cold fronts and cyanobacteria dominance were shown for this reservoir. The horizontal scale changes with the system being decomposed as horizontal heterogeneous units with a non uniform distribution of zooplankton, phytoplankton and bacteria (Tundisi et al., 2008a). The seasonal pattern of variation of the Wedderburn number confirms the successional patterns of the phytoplankton community. At higher Wedderburn number and low wind force cyanobacteria blooms predominate in the surface or subsurface of the reservoir (Tundisi and MatsumuraTundisi, 2008).

The interaction of solar radiation, water and wind regimes influence the cycles of events in the vertical structure of the freshwater ecosystems at tropical and subtropical latitudes (Talling, 1969; Talling and Lemoalle, 1998). Wind seasonality is an important interacting factor as well as the surface cooling that occur during the duration of cold fronts. Wind affects suspended particulate material, turbidity, living and non living planktonic material therefore the cold front introduce a certain irregularity of factor variations. Its impact is dependent upon the duration of 
(a)
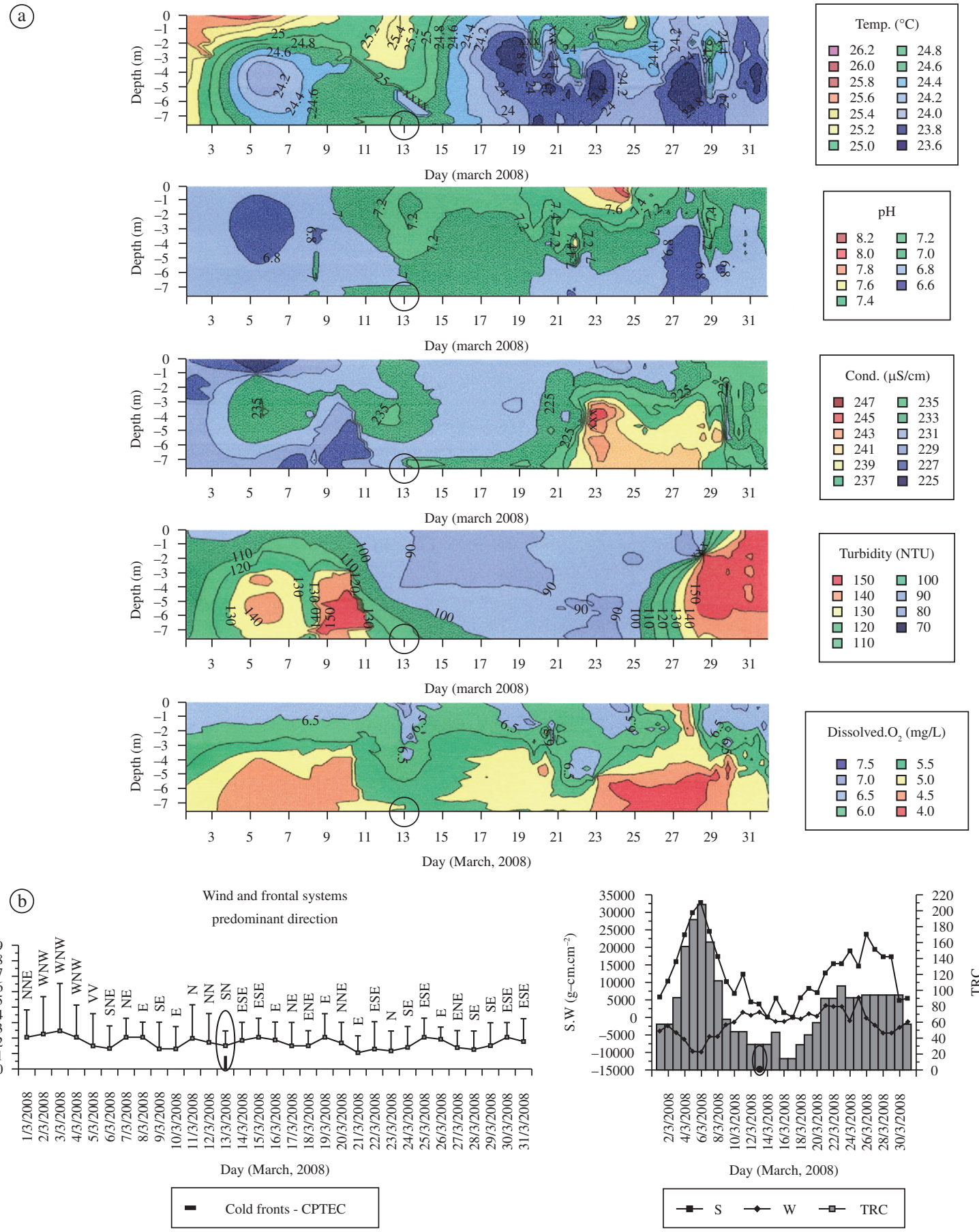

Figure 6. a) Short term sequences of the water column structure in December 2007 measured by a real time monitoring system $\left(\right.$ SMATER) ${ }^{\mathrm{R}}$ at Billings reservoir. The incidence of the cold front is shown; and b) wind and frontal systems, work of the wind, stability and thermal resistance to circulation in December 2007 at Billings reservoir.

the process, the depth of the freshwater ecosystem and its latitude. The impact of precipitation during the cold fronts also, cannot be disregarded. Precipitation can discharge nutrients by drainage introducing the "new nutrient component" to the lake or reservoir, therefore increasing the pool of nutrients available to phytoplankton growth. A strong effect of the cold front, not so common, dependent upon the duration of the phenomenon and the strength of the winds is the fish mortality in some lakes or shallow reservoirs at various latitudes. 
(a)
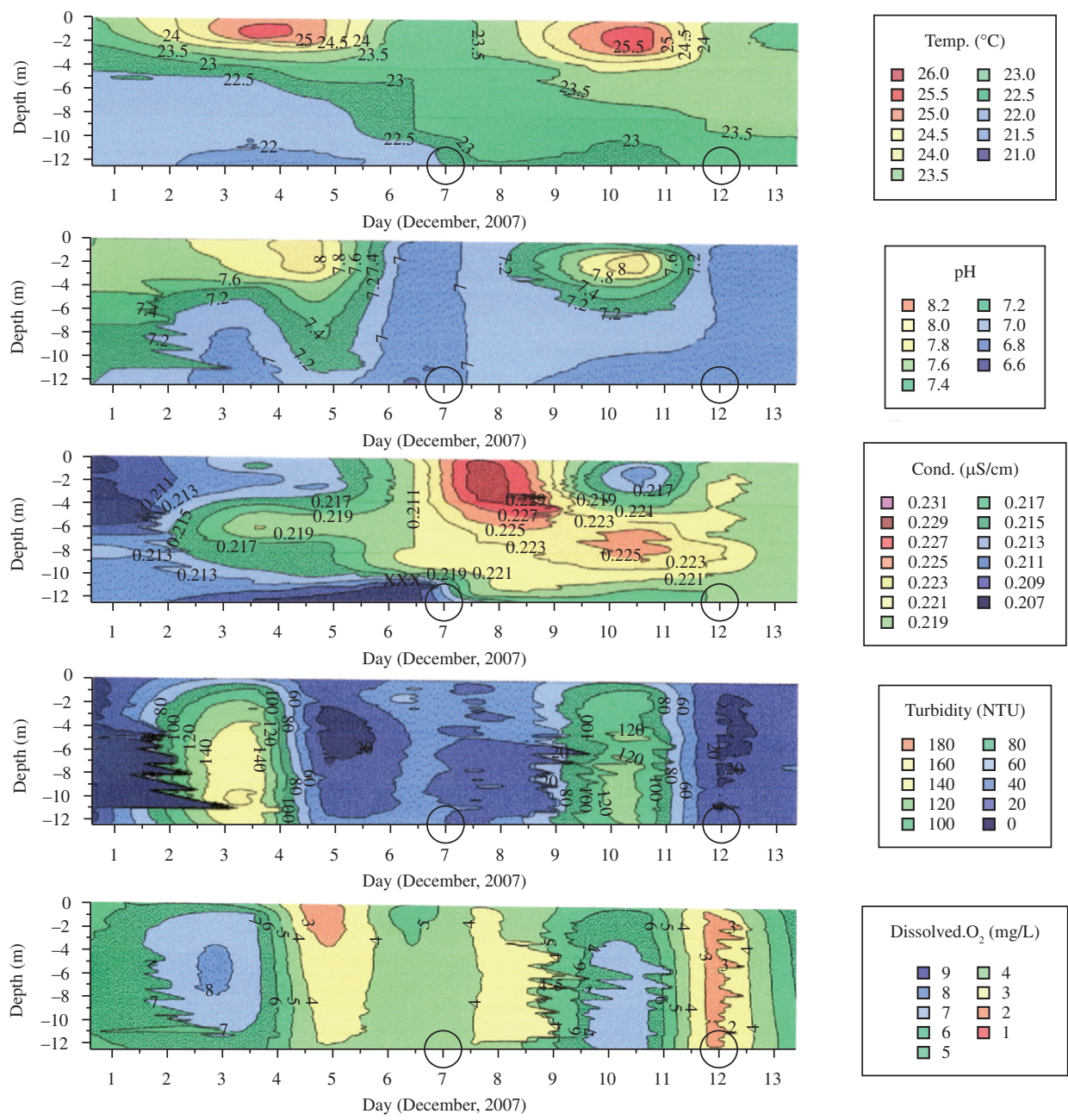

(b)
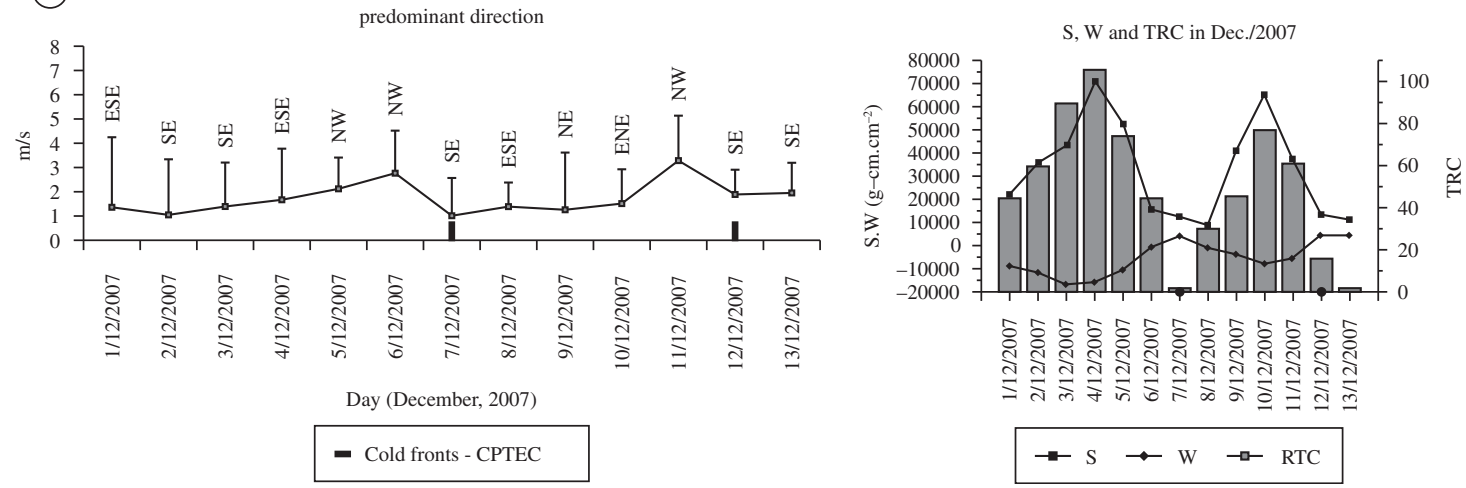

Figure 7. a) Short term sequences of the water column structure in March 2008, measured by a real time monitoring system $\left(\right.$ SMATER) ${ }^{\mathrm{R}}$ AT Billings reservoir. The incidence of the cold front is shown; b) Wind and frontal systems, work of wind, stability and thermal resistance to circulation during March 2008 at Billings reservoir.

Considering now the existing information, it is possible to propose a mechanism of functioning of reservoirs and lakes of southeastern Brazil related to the patterns of cold fronts/instability and absence of cold fronts/stability (Table 1).
This table is based on Demers et al. (1951), Reynolds (1997), Tundisi et al. (2004) and Branco et al. (2009). It is an attempt to propose a model of phytoplankton succession for lakes and reservoirs based on the instability of the water column and the absence or presence of the cold front. The 
Table 1. Phytoplankton responses to cold fronts through the proximal agent vertical mixing or stability.

\begin{tabular}{|c|c|c|}
\hline Cold fronts & Proximal agent & Phytoplankton response \\
\hline 1) No cold fronts & $\begin{array}{l}\text { No vertical or horizontal mixing; nutrients } \\
\text { available only through regeneration. }\end{array}$ & Cyanobacterial blooms. \\
\hline $\begin{array}{l}\text { 2) Moderate vertical } \\
\text { mixing previous cold front }\end{array}$ & Alternating periods of stability and mixing. & $\begin{array}{c}\text { Cyanobacterial blooms start to break } \\
\text { down. Selection for chlophyceae and } \\
\text { small diatoms. }\end{array}$ \\
\hline 3) Cold front & $\begin{array}{l}\text { Changing light environment. Nutrients } \\
\text { continuously replenished. Vertical and } \\
\text { horizontal mixing (very intense). }\end{array}$ & $\begin{array}{l}\text { Diatoms and chlorophyceae } \\
\text { predominate. }\end{array}$ \\
\hline 4) Cold front dissipates & $\begin{array}{c}\text { Beginning of a new cycle of stability. } \\
\text { Increase of light and nutrients in the stable } \\
\text { layer. }\end{array}$ & $\begin{array}{l}\text { Beginning of cyanobacterial growth. } \\
\text { Pre bloom conditions. }\end{array}$ \\
\hline
\end{tabular}

prediction of the frequency of cyanobacteria blooms is one of the best possibilities of application since enables water managers to organize and prepare water treatment accordingly to the water quality at the source of supply.

Since cold fronts contribute towards deterioration of the water quality for public supply, the follow up of the impact of the cold fronts is a fundamental priority (Tundisi et al., 2008b).

Acknowledgements - The authors thank FAPESP, CNPQ, FINEP for many years of support for their reservoir ecosystem work. The author thank the Secretaria do Verde e Meio Ambiente, Prefeitura Municipal de S. Paulo- Process number: 056/ SVMA/ 2008 for the support to their work in the Guarapiranga/ Billings reservoirs. Also the support of DERSA (Government of S. Paulo State) is gratefully acknowledged. Biota FAPESP supported field work.

\section{References}

ANDRADE, KM., 2005. Climatologia e comportamento dos sistemas frontais sobre a América do Sul. São José dos Campos: INPE. 185 p. Dissertação de Mestrado em Meteorologia. (INPE14056- TDI/ 1067).

ARCIFA, MS., MESCHIATTI, AJ. and GOMES, EAT., 1990. Thermal regime and stability of a tropical shallow reservoir: Lake Monte Alegre, Brazil. Revue d'Hydrobiologie Tropicale, vol. 23 , no. 4, p. 271-281.

BARBOSA, FAR. and PADISÁK, J., 2002. The forgotten lake stratification pattern: atelomixis, and its ecological importance. Verhandlungen Internationale Vereinigung Limnolologie, vol. 28, p. $1385-1395$.

BRANCO, CWC., KOSLOWSKY-SUZUKI, B., SOUSE-FILHO, IF., GUARINO, AWS. and ROCHA, RJ., 2009. Impact of climate on the vertical water column structure of Lajes reservoir (Brazil): a tropical reservoir case. Lakes and Reservoirs: Research and Management, vol. 14, p. 175-191.

CARABALLO, P., ALMEIDA, F., FORSBERG, B. and LEITE, R., 2010. Vertical mixing in an amazonian floodplain lake: description of a friagem phenomenon. Limnol. \& Oceanogr. (in press).

CAVALCANTI, IFA. and KOUSKY, VE., 2009. Parte I - Sistemas meteorológicos que afetam o tempo na América do Sul: frentes frias sobre o Brasil. In CAVALCANTI, IF A., FERREIRA, NJ.,
SILVA, MGAJ. and SILVA DIAS, MAF. (Ed.). Para entender tempo e clima. São Paulo: Oficina de Textos. p. 135-147.

FEARNSIDE, PM., 1995. Hydroeletric dams in the Brazilian Amazon as sources of "greenhouse"gases. Environmental Conservation, vol. 22, no. 1, p. 7-19.

GANF, GC., 1974. Incident solar irradiance and underwater light penetration as factors controlling the chlorophyll a content of a shallow equatorial lake (Lake George, Uganda). Journal of Ecology, vol. 62, p. 593-609.

HARRIS, GP., 1980. Temporal and spatial scales in phytoplankton ecology. mechanisms, methods, models, and management. Canadian Journal of Fisheries and Aquatic Sciences, vol. 37, no. 5 , p. 877-900.

HARRIS, GP., 1986. Phytoplankton ecology: structure, function and fluctuation. Londres: Chapman and Hall.

LIMA, WV., TUNDISI, JG. and MARINS, MA., 1979. A systemic approach to the sensitivity of Melosira italica (Her). Kutz. Brazilian Journal of Biology, vol. 39, no. 3, p. 559-563.

LUZIA, AP., 2009. Estrutura organizacional do fitoplâncton nos sistemas lóticos e lênticos da bacia do Tietê-Jacaré (UGRHTietê-Jacaré) em relação à qualidade da água e estado trófico. São Carlos: Departamento de Ecologia e Recursos Naturais, Universidade Federal de São Carlos. 169 p. Tese de Doutorado em Ciências Biológicas.

MELACK, JM. and FISHER, TR., 1990. Comparative limnology of tropical floodplain lakes with an emphasis on the central Amazon. Acta Limnologia Brasiliensia, vol. 3, p. 1-48.

MORAIS, MA., CASTRO, WAC. and TUNDISI, JG., 2010. Climatologia de frentes frias sobre a região metropolitana de São Paulo (RMSP), e sua influência na limnologia dos reservatórios de abastecimento de água. Revista Brasileira de Metereologia, vol. 25 , no. 2 , p. 213- 225 .

PADISAK, J., 1993. The influence of different disturbance frequencies on the species richness, diversity and equitability of phytoplankton in shallow lakes. Hydrobiologia, vol. 249, p. 135-156.

PADISÁK, J., BARBOSA, F., KOSCHEL, R. and KRIENITZ, L., 2003. Deep layer cyanoprokaryota maxima in temperate and tropical lakes. Archives Hydrobiologica Special Issues on Advanced Limnology, vol. 58, p. 175-199. 
PASSERINI, MD., 2010. Influência das frentes frias nos mecanismos de funcionamento da represa da UHE Carlos Botelho (Lobo/ Broa) - Itirapina - SP, dos pontos de vista químico, físico e biológico. São Carlos: Departamento de Ecologia e Recursos Naturais, Universidade Federal de São Carlos. 111 p. Dissertação de Mestrado em Ciências Biológicas.

REYNOLDS, CS., 1997. Vegetation processes in the pelagic: a model for ecosystem theory. In KINNE, O. (Ed). Excellence in ecology. Oldendorf Luke, Germany: Ecology Institute. 371 p.

TALLING, JF. and LEMOALLE J., 1998. Ecological dynamics of tropical inland waters. Cambridge: Cambridge University Press. $441 \mathrm{p}$.

TALLING, JF., 1969. The incidence of vertical mixing, and some biological and chemical consequences in tropical Afircan lakes. Verhandlungen Internationale Vereinigung Limnolologie, vol. 17, p. 998-1012.

TUNDISI, JG. and MATSUMURA-TUNDISI, T., 1995. The Lobo-Broa Ecosystem Research. In TUNDISI, JG., BICUDO, CFM. and MATSUMURA-TUNDISI, T. (Ed.). Limnology in Brazil. Rio de Janeiro: Academia Brasileira de Ciências, Sociedade Brasileira de Limnologia. p. 219-244.

-, 2008. Limnologia. São Paulo: Oficina de textos. 632 p.

TUNDISI, JG., 1983. A review of basic ecological processes interacting with production and standing-stock of phytoplankton in lake and reservoirs in Brazil. Hydrobiologia, vol. 100, p. 223-243.

TUNDISI, JG., FORSBERG, BR., DEVOL, A., ZARET, T., MATSUMURA-TUNDISI, T., SANTOS, A., RIBEIRO, J. and
HARDY, E., 1984. Mixing patterns in Amazon lakes. Hydrobiologia, vol. 108 , p. 3-15.

TUNDISI, JG., MATSUMURA-TUNDISI, T. and ABE, DS., 2007. Climate Monitoring before and during limnological studies: a needed integration. Brazilian Journal of Biology, vol. 67, no. 4, p. 795-796

-, 2008a. The ecological dynamics of Barra Bonita (Tietê River, SP, Brazil) reservoir: implications for its biodiversity. Brazilian Journal of Biology, vol. 68, no. 4, p. 1079-1098. Suppl.

TUNDISI, JG., MATSUMURA-TUNDISI, T. and TUNDISI, JEM., 2008b. Reservoirs and human well being: new challenges for evaluating impacts and benefits in the neotropics. Brazilian Journal of Biology, vol. 68, no. 4, p. 1133-1135. Suppl.

TUNDISI, JG., MATSUMURA-TUNDISI, T., ARANTES JUNIOR, JD., TUNDISI, JEM., MANZINI, NF. and DUCROT, R., 2004. The response of Carlos Botelho (Lobo, Broa) reservoir to the passage of cold fronts as reflected by physical, chemical, and biological variables. Brazilian Journal of Biology, vol. 64, no. 1 , p. 177-186.

TUNDISI, JG., SEBASTIEN, NY., MATSUMURA-TUNDISI, T., TUNDISI, JEM. And MANZINI, NF., 2006. The responses of reservoir of southeastern Brazil to the passage of cold fronts as reflected by physical, chemical and biological variables. Verhandlungen Internationale Vereinigung Limnolologie, vol. 29, p. 2124-2128.

WILLIAM, JS. and GOLDMAN., 1975. Succession rates in lakes phytoplankton communities. Verhandlungen Internationale Vereinigung Limnolologie, vol. 19, p. 808-811. 